\title{
More Than Skin Deep - the Effects of Ultraviolet Radiation on Cathepsin K and Progerin Expression in Cultured Dermal Fibroblasts
}

\author{
Igor Aleksander Bednarski ${ }^{1}{ }^{\prime}$ \\ Magdalena Ciążyńska ${ }^{2}$ \\ Jacek Kabziński ${ }^{3}$ \\ Ireneusz Majsterek ${ }^{3}$ \\ Dorota Sobolewska-Sztychny' \\ Joanna Narbutt' \\ Aleksandra Lesiak' \\ 'Department of Dermatology, Pediatric \\ Dermatology and Dermatological \\ Oncology, Medical University of Lodz, \\ Lodz, 91-347, Poland; ${ }^{2}$ Nicolaus \\ Copernicus Multidisciplinary Centre for \\ Oncology and Traumatology, Lodz, 93- \\ 513, Poland; ${ }^{3}$ Department of Chemistry \\ and Clinical Biochemistry, Medical \\ University of Lodz, Lodz, 90-136, Poland
}

Correspondence: Igor Aleksander Bednarski

Department of Dermatology, Pediatric Dermatology and Dermatological Oncology, Medical University of Lodz, Kniaziewicza I/5, Lodz, 91-347, Poland Email igorbednarskiv@gmail.com
Introduction: Photoaging is a premature skin aging developing secondarily to the excessive exposure to ultraviolet radiation. Due to its complexity, an exact mechanism of photoaging has not been found yet; however, recent research has shown two new emerging players in this process - cathepsin $\mathrm{K}$ and progerin.

Aim: To evaluate how different wavelengths of ultraviolet radiation (UVA, narrowband UVB and broadband UVB) influence cathepsin $\mathrm{K}$ and progerin protein and mRNA expression in dermal cultured fibroblasts.

Materials and Methods: Primary human dermal fibroblasts (Detroit 551, ATCC CCL-110) were cultured and irradiated with UVA, narrowband UVB (UVBnb) and broadband UVB (UVBwb). Fibroblasts were irradiated with 2 protocols: single high-dose exposure to UVR with protein/mRNA extraction immediately after exposure, $24 \mathrm{~h}$ after exposure and $48 \mathrm{~h}$ after exposure, and repeated ( $0 \mathrm{~h}, 24 \mathrm{~h}$ and $48 \mathrm{~h}$ ) low-dose exposure to UVR with protein/mRNA extraction $48 \mathrm{~h}$ after first exposure.

Results: Single high doses of UVA, UVBwb and UVBnb resulted in decreased expression of cathepsin $\mathrm{K}$ and progerin protein/mRNA in all subsequent time points. Repeated exposure to low doses of UVA results in significant increase of progerin mRNA and significant decrease of progerin protein after $48 \mathrm{~h}$, but repeated exposure to UVBwb and UVBnb resulted in decreased progerin mRNA and protein expression. Repeated exposure to UVA, UVBwb and UVBnb resulted in decreased cathepsin $\mathrm{K}$ protein and mRNA expression.

Conclusion: The results suggest that there could be another progerin/cathepsin $\mathrm{K}$ regulatory pathway, which has not been described yet. Being contradictory with previous research, the influence of ultraviolet radiation on progerin and cathepsin $\mathrm{K}$ needs to be further elucidated. Keywords: progerin, cathepsin K, photoaging

\section{Introduction}

Photoaging is a continuous and progressive process occurring in response to chronic exposure to ambient sunlight, which is a mixture of ultraviolet radiation types A and B (UVA, UVB), however their properties differ. UVA affects the deeper layers of the skin responsible for the degradation of the extracellular matrix and increased formation of reactive oxygen species within the dermis, ${ }^{1,2}$ UVB, on the other hand, can stimulate inflammation and formation of DNA photolesions. ${ }^{3,4}$ The combination of these wavelengths results in complex interplay between angiogenic, immunosuppressive and elastolytic activity, and their exact effects are still under investigation. It also remains unsolved how different types of ultraviolet 
radiation (UVR) participate in photoaging. Thus, photoaging should be considered premature skin aging secondary to excessive exposure to UVR. ${ }^{5}$ One of the hallmarks of photoaging is the aggregation of dystrophic elastin which can occur via its extracellular degradation orchestrated by matrix metalloproteinases, ${ }^{6,7}$ as well as intracellular degradation predominantly controlled by cathepsin $\mathrm{K}$ (CatK), ${ }^{8}$ which degrades elastin in the lysosomes of dermal fibroblasts. $^{7}$ Cathepsin $\mathrm{K}$ belongs to the cysteine protease family, and is involved in the degradation of collagen I, elastin and gelatine. ${ }^{9,10}$ Cathepsin $\mathrm{K}$, predominantly expressed in human osteoclasts, is responsible for bone remodelling, however the latest research shows that cathepsin $\mathrm{K}$ could be involved in the pathogenesis of skin tumors e.g. malignant melanoma and basal cell carcinoma, ${ }^{11,12}$ as well as skin aging $^{13}$ and the development of psoriasis-like lesions. ${ }^{14}$ While matrix metalloproteases have been extensively studied in terms of photoaging, there is still little known about cathepsin $\mathrm{K}$ in this context.

In addition to the extracellular matrix disequilibrium present in photoaged skin it seems that a new key player has emerged - a progerin. For several years progeroid syndromes, especially Hutchinson-Gilford progeria syndrome (HGPS), ${ }^{15}$ served as model diseases in research concerning all types of premature aging. HGPS is caused by a de novo point G608G (GGC $\rightarrow$ GGT) mutation in the LMNA gene encoding prelamin A. ${ }^{16}$ Normally, prelamin A undergoes a series of post-translational modifications which include attaching a farnesyl group onto C-terminal cysteine and cleavages catalyzed by a zinc-metalloprotease ZMPSTE24. ZMPSTE24 cleaves $15 \mathrm{C}$-terminal residues in prelamin A (aa 647-661) and removes farnesyl from prelamin A, giving rise to fully functional lamin A, which along with lamin $\mathrm{B}$ and $\mathrm{C}$ maintains the structural stability of the cell nucleus. ${ }^{17}$ Farnesylation is a key step in this process, allowing prelamin A to attach temporarily to the nuclear membrane. ${ }^{16}$ In HGPS, the point mutation in the LMNA gene results in a cryptic splicing site within exon 11 which disrupts the removal of 1503 '-terminal nucleotides from this exon, resulting in synthesis of $\triangle 150 \mathrm{LMNA}$ mRNA. After translation of $\triangle 150 L M N A$ mRNA, an isoform of lamin A with 50 amino acids ( $\triangle 50$ lamin $\mathrm{A})$ deleted emerges, and is commonly referred to as progerin. ${ }^{17}$ Since the ZMPSTE24 cleavage site is lost, progerin remains constantly farnesylated thus resulting in its accumulation within the nuclear envelope and an inability to stabilize the cell nucleus. ${ }^{18}$ The nucleus, devoid of lamin $\mathrm{A}$, is abnormally shaped and has a reduced ability to divide, due to the disruption of chromatin remodeling, impaired DNA repair mechanisms and telomere shortening. ${ }^{15,19-21} \mathrm{It}$ has also been shown that the abnormal accumulation of progerin occurs, not only in HGPS, but also in normally senescing cells, ${ }^{16,22}$ indicating that increased progerin expression could be considered as a hallmark of cell aging, however the results are still inconclusive. ${ }^{23}$ One of the most recent findings indicates that progerin could also be associated with UV-induced skin aging. ${ }^{15}$

Due to many non-specific and contradictory findings regarding the involvement of cathepsin $\mathrm{K}$ and progerin in photoaging and their promising role in skin anti-aging therapies, ${ }^{7,24}$ we aimed to evaluate how different wavelengths of UVR influence their expression in cultured dermal fibroblasts.

\section{Materials and Methods Cell Cultures}

Primary human dermal fibroblasts (Detroit 551, ATCC CCL-110) were cultured using manufacturer's protocol. Eagle's Minimum Essential Medium (EMEM) with addition of $5 \%$ Fetal Bovine Serum (FBS) and $1 \%$ of Penicillin-Streptomycin solution was used as medium. All reagents were purchased at ATCC.

\section{UVA/UVB Irradiations}

Irradiations were performed using TL20W/01 narrowband UVB lamps with spectral output 305-315 nm (Philips, Germany), TL20W/12 UVB lamps with spectra output 285-350 nm and TL10RS UVA lamps with spectral output 320-400 nm (Philips, Germany). The exact dose and irradiation time were calculated according to manufacturer's protocols. In the course of the experiment, cells were irradiated with UVA, UVB narrowband (UVBnb) and UVB broadband (UVBwb) according to the protocol:

\section{Exposure to a High Dose of Radiation}

- UVA $150 \mathrm{~kJ} / \mathrm{m}^{2}$, protein was isolated immediately after exposure, $24 \mathrm{~h}$ after exposure and $48 \mathrm{~h}$ after exposure;

- UVBnb $300 \mathrm{~J} / \mathrm{m}^{2}$, protein was isolated immediately after exposure, $24 \mathrm{~h}$ after exposure and $48 \mathrm{~h}$ after exposure;

- UVBwb $300 \mathrm{~J} / \mathrm{m}^{2}$, protein was isolated immediately after exposure, 24 hours after exposure and $48 \mathrm{~h}$ after exposure; 
Exposure to a Low, Repetitive Dose of Radiation

- UVA $50 \mathrm{~kJ} / \mathrm{m}^{2}$ repeated after $24 \mathrm{~h}$ and $48 \mathrm{~h}$ (total dose $150 \mathrm{~kJ} / \mathrm{m}^{2}$ ), protein isolated after the third exposure;

- UVBnb $100 \mathrm{~J} / \mathrm{m}^{2}$ repeated after $24 \mathrm{~h}$ and $48 \mathrm{~h}$ (total dose $300 \mathrm{~J} / \mathrm{m}^{2}$ ), protein isolated after the third exposure;

- UVBwb $100 \mathrm{~J} / \mathrm{m}^{2}$ repeated after $24 \mathrm{~h}$ and $48 \mathrm{~h}$ (total dose $300 \mathrm{~J} / \mathrm{m}^{2}$ ), protein isolated after the third exposure.

\section{Western Blots}

Cells were lysed in EBC buffer (50 mM Tris pH 8.0; 120 $\mathrm{mM} \mathrm{NaCl} ; 0.5 \% \mathrm{NP}-40$ ) supplemented with protease and phosphatase inhibitors. Total protein $(100 \mu \mathrm{g})$ was resolved on denaturing $10 \%$ polyacrylamide gels, transferred to nitrocellulose membranes or PVDF (Millipore), and blotted with the indicated primary antibodies: Anticathepsin K antibody and Anti-progerin antibody (Abcam, USA) followed by incubation with appropriate secondary antibody. Sites of antibody binding were visualized by enhanced chemiluminescence detection kit (Bio-Rad).

\section{qPCR}

Total RNA was extracted with the RNAqueous ${ }^{\mathrm{TM}}$ Total RNA Isolation Kit and reverse transcribed into cDNA using a RevertAid First Strand cDNA Synthesis Kit according to the manufacturer's protocol. Quantitative real-time PCR was performed using a CFX96 Touch Real-Time PCR (BioRad). The reaction $(12 \mu \mathrm{L})$ contained $0.2 \mathrm{nmol}$ of forward and reverse primer, cDNA template, water and $\mathrm{SYBR}^{\circledR}$ Green PCR Master Mix. Reactions were incubated at $95^{\circ} \mathrm{C}$ for $10 \mathrm{~min}$, followed by 40 cycles of $95^{\circ} \mathrm{C}$ for $15 \mathrm{~s}$ and $56^{\circ} \mathrm{C}$ for $1 \mathrm{~min}$. The following gene-specific primers were used: F: $5^{\prime}$ GGAGCTGACTTCCGCAATCCCG-3' and R: 5'TGTCTGGCTTCGTTTCGGCAGC-3' for cathepsin K; F: 5'-TCAGGAGCCCAGAGCCCCCAGAAC-3' and R: 5'GGGTTATTTTTCTTTGGCTTCA-3' for progerin. Gene expression levels were normalized to the level of GADPH using the following primers: F: 5'-ACAGTTGCCA TGTAGACC-3' and R: 5'-TTGAGCACAGGGTACTTTA-3' and quantitative gene expression was calculated with comparative $\Delta \mathrm{Ct}$ method.

\section{Results UVA}

UVA decreased cathepsin $\mathrm{K}$ and progerin protein expression in cultured primary human fibroblasts. It was observed both after single $\left(150 \mathrm{~kJ} / \mathrm{m}^{2}\right)$ and repeated $\left(3 \times 50 \mathrm{~kJ} / \mathrm{m}^{2}\right)$ irradiation which resembled acute and chronic exposure to
UVA, respectively. It was found that a single high $150 \mathrm{~kJ} / \mathrm{m}^{2}$ dose of UVA irradiation resulted in decreased expression of cathepsin $\mathrm{K}$ protein in all subsequent time points $(77 \%$, $79 \%$ and $88 \%$ of loading control expression), however no significant difference between each time point has been noted $(\mathrm{p}=0.2177)$. RT-qPCR showed decrease of cathepsin $\mathrm{K}$ mRNA in all subsequent time points (- $\Delta \mathrm{Ct}$ values: -5.4 , -8.1 and $-1.8, p=0.0087)$. Further analysis did not reveal significant differences between $\mathrm{T} 0$ and $\mathrm{T} 1 / \mathrm{T} 2$ points. Repeated low doses of UVA $\left(3 \times 50 \mathrm{~kJ} / \mathrm{m}^{2}\right)$ decreased cathepsin $\mathrm{K}$ protein expression to a much greater extent than the single high dose of UVA $\left(150 \mathrm{~kJ} / \mathrm{m}^{2}\right)(70 \%$ vs $88 \%$ of loading control expression respectively, $\mathrm{p}=0.0171)$, however the differences between cathepsin K mRNA levels were not significant $(\mathrm{p}=0.8585)$.

The single high $150 \mathrm{~kJ} / \mathrm{m}^{2}$ dose of UVA irradiation resulted in decreased expression of progerin in subsequent time points $(22 \%, 22 \%$ and $78 \%$ of loading control expression). The increase of progerin protein expression after 48 $\mathrm{h}$ compared with $0 \mathrm{~h}$ has been found to be significant $(\mathrm{p}=$ $0.0001)$. RT-qPCR revealed a decrease of progerin mRNA in all subsequent time points ( $-\Delta \mathrm{Ct}$ values: $-4.2,-3.4$, -2.7 respectively). Repeated low doses of UVA ( $3 \times 50$ $\mathrm{kJ} / \mathrm{m}^{2}$ ) decreased progerin protein expression to a much greater extent than a single high dose of UVA $\left(150 \mathrm{~kJ} / \mathrm{m}^{2}\right)$ ( $43 \%$ vs $72 \%$ of loading control expression respectively, $p$ $=0.0033)$. RT-qPCR revealed that repeated exposure to low doses of UVA results in a significant increase of progerin mRNA after $48 \mathrm{~h}$ compared with irradiation with a single high dose $(0.3$ vs $-2.7, p=0.0116$ respectively).

\section{Broadband UVB}

Cathepsin K protein expression decreased to $27 \%$ in $\mathrm{T} 0$, to $19 \%$ in $\mathrm{T} 1$ and to $56 \%$ in $\mathrm{T} 2$ which has been partially reflected in mRNA levels $(-4$ in T0, 0.4 in T1 and -3.8 in T2). Repeated exposure to UVBwb decreased cathepsin $\mathrm{K}$ protein expression and mRNA levels $(61 \%$, $-\mathrm{dCt}=$ $-2.1)$. Exposure to a single high dose of UVBwb resulted in decreased progerin protein expression $(\mathrm{T} 0=27 \%, \mathrm{~T} 1$ $=19 \%, \mathrm{~T} 2=56 \%)$ and progerin mRNA $(\mathrm{T} 0=-1.8, \mathrm{~T} 1=$ $-3.5, \mathrm{~T} 2=-1.9)$. Repeated low dose of UVBwb decreased progerin protein expression to a much greater extent than a single high dose ( $22 \%$ vs $56 \%, \mathrm{p}=0.0004)$, however it has not been observed for progerin mRNA $(-1.9$ vs -1.6 respectively). 


\section{Narrowband UVB}

Irradiation with a single high dose of UVBnb also resulted in a decrease of cathepsin $\mathrm{K}$ protein expression $(\mathrm{T} 0=$ $92 \%, \mathrm{~T} 1=88 \%, \mathrm{~T} 2=63 \%$, the difference between $\mathrm{T} 0$ and $\mathrm{T} 2$ was significant, $\mathrm{p}<0.05$ ) with decreased mRNA levels $(\mathrm{T} 0=-1.5, \mathrm{~T} 1=-3.0, \mathrm{~T} 2=-1.5)$. Repeated exposure to UVBnb significantly decreased cathepsin $\mathrm{K}$ protein and mRNA expression $(47 \%, \mathrm{p}=0.0001 ;-\mathrm{dCt}=$ $-4.4, p=0.0129$ respectively) in comparison to single high UVBnb dose. A single high dose of UVBnb resulted in decreased progerin protein expression $(\mathrm{T} 0=56 \%, \mathrm{~T} 1=$ $58 \%, \mathrm{~T} 2=56 \%$, the difference between $\mathrm{T} 0$ and $\mathrm{T} 1 / \mathrm{T} 2$ was found to be significant) followed by decreased mRNA levels $(\mathrm{T} 0=-1.8, \mathrm{~T} 1=-3.5, \mathrm{~T} 2=-1.9)$. Repeated exposure to UVBnb resulted in a significant decrease of progerin protein $(21 \%, \mathrm{p}<0.0001)$ and an increase in mRNA levels $(-\mathrm{dCt}=-0.4, \mathrm{p}=0.0006)$ compared with single high UVBnb dose. Detailed results are shown in Tables 1-2 and-figure2.

\section{Discussion}

UV radiation reaching Earth consists of several wavelengths with different biological effects. ${ }^{25,26}$ UVA (315-400 nm), which is barely absorbed by DNA, UVB (280-315 nm), which is directly absorbed by DNA inducing photochemical reactions, and UVC (100-280 nm) which hardly reaches Earth's surface. ${ }^{26,27}$ UVA penetrates deeper into the skin and is considered a main factor responsible for extracellular matrix degeneration observed in photoaged skin, although recent studies have shown that UVB is also able to reach into the upper parts of the dermis, and through epidermal-dermal signaling to degrade collagen, which is one of the hallmarks of photoaging. ${ }^{28}$ Cathepsin $\mathrm{K}$ (catK) is considered one of the most potent collagenases due to its ability to degrade type-I collagen at multiple sites. ${ }^{29}$ Increased expression of catK has been found in scars ${ }^{30}$ and skin tumors ${ }^{31,32}$ and has been linked with preserving normal structure of the skin. ${ }^{33}$ Little is known, however, about the influence of UVR on catK activity. Codriansky et al. ${ }^{8}$ found that UVA (dose range from 100 to $500 \mathrm{~kJ} / \mathrm{m}^{2}$ ) induces expression of catK in both cultured neonatal fibroblasts and dermal fibroblasts from skin explants and that its expression is dose-dependent. ${ }^{8}$ Interestingly, they revealed that in old fibroblasts (taken from donors aged 60-67 years old) catK is not activated in response to UVA $\left(300 \mathrm{~kJ} / \mathrm{m}^{2}\right)$ in all measured time points (24 days after irradiation). ${ }^{8}$ Induced expression of catK was also found after UVB irradiation in both neonatal fibroblasts

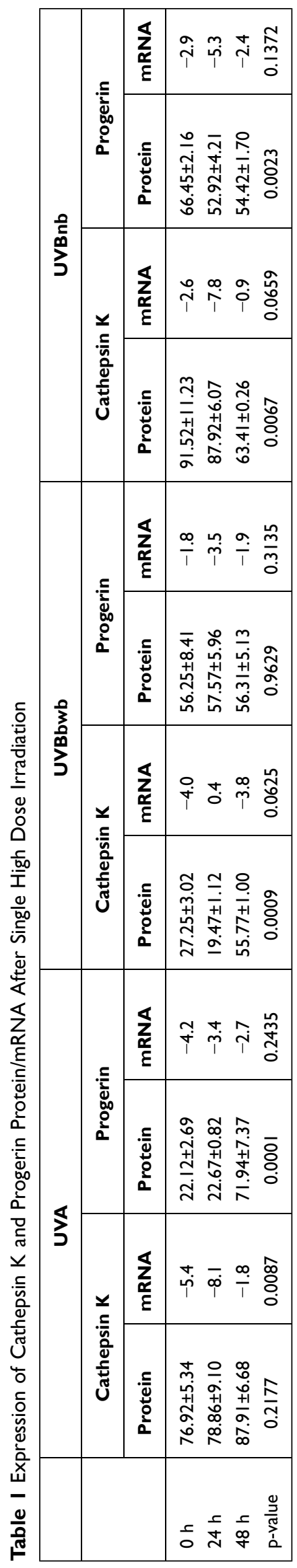


Table 2 Expression of Cathepsin K and Progerin Protein/mRNA After Repeated Low Dose Irradiation vs High Dose Irradiation

\begin{tabular}{|c|c|c|c|c|c|}
\hline Irradiation & & & Single High Dose & Repeated Low Dose & p-value \\
\hline \multirow[t]{4}{*}{ UVA } & Cathepsin & Protein & $87.91 \pm 6.68$ & $69.91 \pm 4.29$ & $0.017 \mid$ \\
\hline & & mRNA & -1.8 & -1.4 & 0.8585 \\
\hline & Progerin & Protein & $71.94 \pm 7.37$ & $42.5 I \pm 4.35$ & 0.0033 \\
\hline & & mRNA & -2.7 & 0.3 & 0.0116 \\
\hline \multirow[t]{4}{*}{ UVBbwb } & Cathepsin & Protein & $55.77 \pm 1.00$ & $61.18 \pm 6.23$ & 0.2115 \\
\hline & & mRNA & -3.8 & -2.1 & 0.5149 \\
\hline & Progerin & Protein & $56.31 \pm 5.13$ & $22.34 \pm 2.15$ & 0.0004 \\
\hline & & mRNA & -1.9 & -1.6 & 0.8165 \\
\hline \multirow[t]{4}{*}{ UVBnb } & Cathepsin & Protein & $63.4 I \pm 0.26$ & $46.63 \pm 2.05$ & 0.0001 \\
\hline & & mRNA & -0.9 & -4.4 & 0.0129 \\
\hline & Progerin & Protein & $54.42 \pm 5.70$ & $20.93 \pm 2.96$ & $<0.0001$ \\
\hline & & mRNA & -2.4 & -0.4 & 0.0006 \\
\hline
\end{tabular}

$\left(100 \mathrm{~J} / \mathrm{m}^{2}\right.$ dose) and dermal fibroblasts from skin explants ( 200 and $500 \mathrm{~J} / \mathrm{m}^{2}$ doses) but was not so pronounced as with UVA. $^{8}$ These findings were confirmed by $\mathrm{Xu}$ et al. ${ }^{7}$ who observed a dose-dependent induction of catK mRNA and protein after exposure to 100,200 and $300 \mathrm{~kJ} / \mathrm{m}^{2}$ UVA doses in human dermal fibroblasts isolated from circumcised foreskins of donors aged 6-9 years old. ${ }^{7}$ In our study, we currently have not obtained catK mRNA induction or increased protein expression after exposure to both acute and chronic UVA/UVB irradiation; catK mRNA and protein expression was decreased as observed in old fibroblasts. Since we used irradiation doses within the range of previously performed experiments $\left(150 \mathrm{~kJ} / \mathrm{m}^{2} \mathrm{UVA}, 300 \mathrm{~J} / \mathrm{m}^{2}\right.$ UVB) it seems that fetal dermal fibroblasts do not express catK activity in response to UVA/UVB irradiation, however more studies are needed to prove this hypothesis.

HGPS is a rare genetic disorder driven by an accumulation of an abnormal form of lamin A, known as progerin. ${ }^{22}$
For several years HGPS served as a model disease in the studies concerning aging processes suggesting that progerin expression could be linked with inflammation, ${ }^{34}$ neurodegeneration, ${ }^{35}$ and carcinogenesis, ${ }^{36}$ however no exact mechanisms have been established yet. It also remains unsolved how progerin participates in premature skin aging which is observed in patients with HGPS as loss of subcutaneous fat, alopecia, nail dystrophy, thinning and excessive wrinkling of the skin. ${ }^{16,37}$ In normal conditions, skin differentiation and stratification is preserved by a mechanism in which epidermal stem cells undergo asymmetric cell division producing two daughter cells, with one remaining in the basal lamina, and the second migrates to suprabasal layers and further differentiates. ${ }^{38}$ It is hypothesized that, in HGPS, progerin expression causes stem cell depletion which eventually results in a reduced capacity to maintain tissue homeostasis. ${ }^{39,40}$ To study the potential role of progerin in premature skin aging Sola-Carvajal et al. ${ }^{41}$ using an
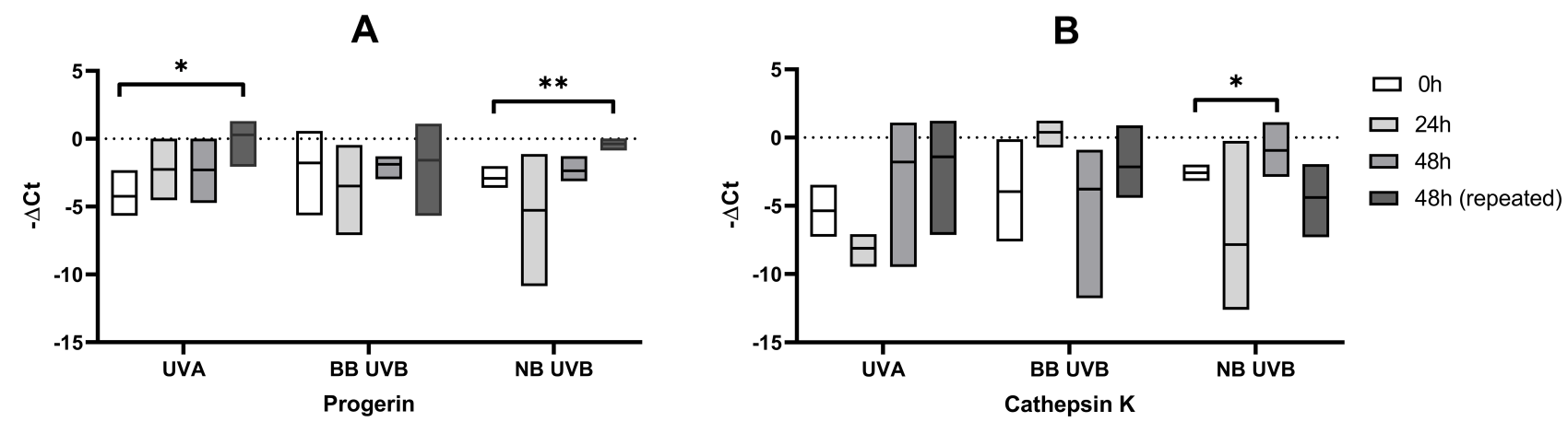

Figure I Alterations in progerin (A) and cathepsin $\mathrm{K}(\mathbf{B})$ mRNA relative expression $(-\Delta \mathrm{Ct})$ after exposure to different wavelengths of UVR. Asterisks above columns indicate level of statistical significance $\left(* \mathrm{p}<0.05,{ }^{* *} \mathrm{p}<0.00 \mathrm{I}\right)$. Data presented as means (horizontal black line within box) with standard deviation (boxes). 


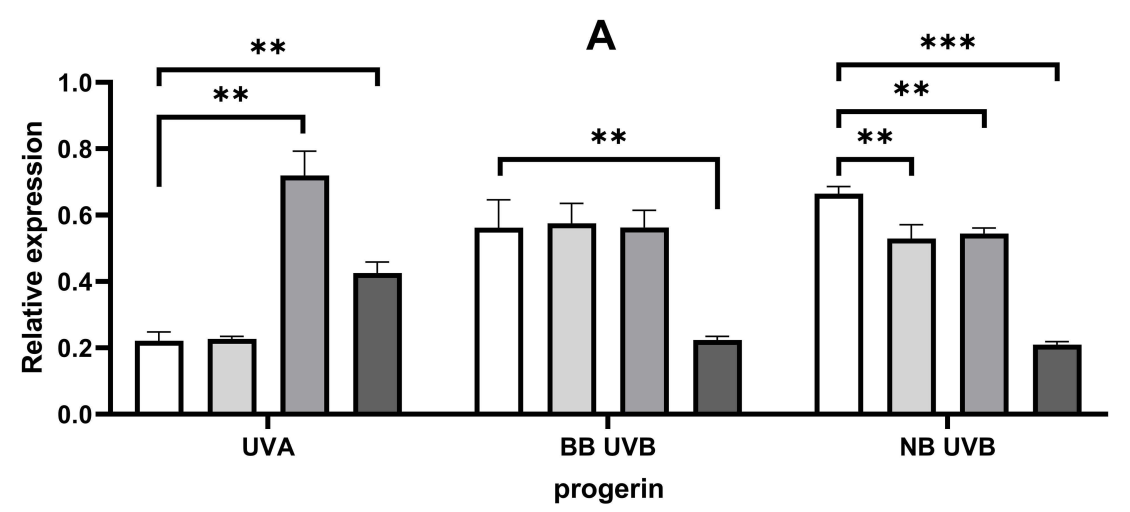

B

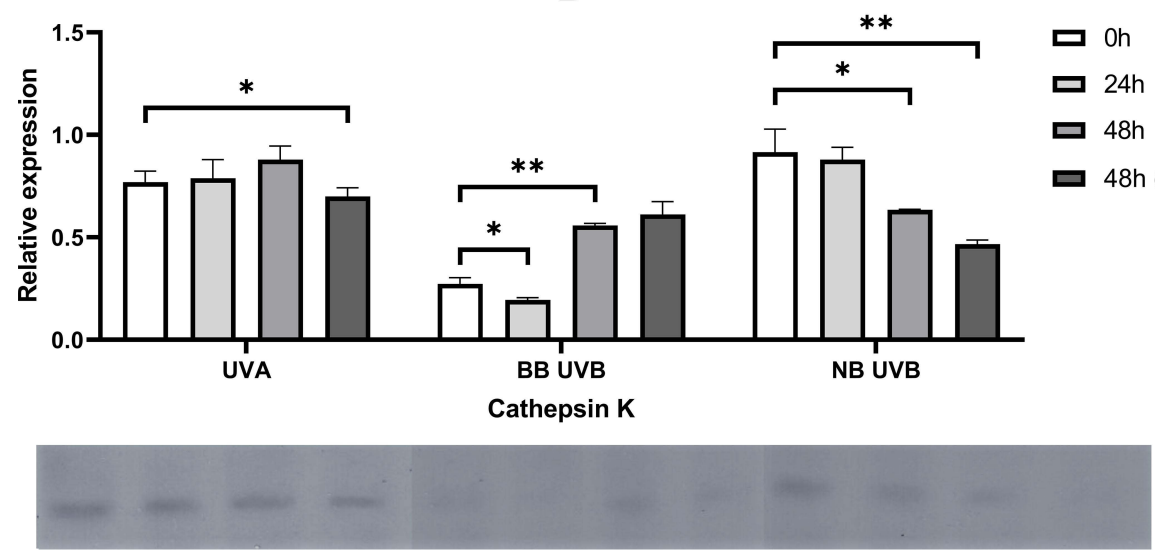

Figure 2 Alterations in progerin (A) and cathepsin $\mathrm{K}(\mathbf{B})$ protein expression after exposure to different wavelengths of UVR. Asterisks above columns indicate level of statistical significance $\left(* \mathrm{p}<0.05,{ }^{* *} \mathrm{p}<0.00 \mathrm{I},{ }^{* * *} \mathrm{p}<0.000 \mathrm{I}\right)$. Data presented as means (boxes) with standard deviation (whiskers). Corresponding Western blot bands are shown below each graph.

HGPS murine model discovered that accumulation of progerin in epidermal stem cells causes a shift toward symmetric cell division, in which both daughter cells are differentiating, eventually leading to depletion of epidermal stem cells and interrupted skin development. ${ }^{41}$ They have also found that the presence of progerin in the nuclear envelope enhances stem cell depletion by the disruption of $\mathrm{Wnt} / \beta$-catenin signaling responsible for the preservation of stem cell equilibrium, which partially explains premature loss of regeneration mechanisms observed in HGPS. ${ }^{41}$ Some recent findings also indicate that UV radiation could induce progerin expression, thus resulting in premature skin aging. ${ }^{15}$ In our previous paper, ${ }^{42}$ we demonstrated that progerin is mainly expressed after excessive exposure to sunlight and that this is almost exclusively limited to dermal fibroblasts, ${ }^{42}$ therefore, to address new questions, we decided to study the effects of different doses of UV radiation on the expression of progerin. In our current study, we showed that a single high dose of UVA irradiation $(150 \mathrm{~J} /$ $\mathrm{m}^{2}$ ) does not induce expression of progerin mRNA and decreases progerin protein expression. It seems to be opposing findings made by Takeuchi and Rünger; ${ }^{15}$ they described increased progerin expression both after single and repeated UVA irradiations. Takeuchi and Rünger revealed that acute exposure of primary human dermal fibroblasts to different doses of UVA ( 80 and $120 \mathrm{~kJ} / \mathrm{m}^{2}$ ) results in an increase of progerin mRNA expression 8 and 24 hours after irradiation. Interestingly, progerin mRNA induction after exposure to repeated doses of UVA has been observed only in aged cells taken from older donors and they did not observe induction of progerin even after both acute and chronic UVB irradiations, which contradicts our results. Nevertheless, several differences in study design should be emphasized; we performed our study on a cultured commercial line of fibroblasts, irradiating them with higher acute doses of UVA, but lower chronic UVA 
doses - in our study, we decided to employ equal cumulative doses of UVA and UVB; we also decided to use both narrow and broadband UVB irradiation to evaluate whether the induction of progerin is wavelength-dependent. We observed a decrease of progerin mRNA after both narrow and broadband UVB after 24 hours, which suggests that UVB could also be responsible for the accumulation of progerin, which has not been previously observed. We hypothesize that the formation of a lamin A-progerin complex is not only limited to UVA, but also appears in UVB, which would explain the observed decrease in progerin protein expression after irradiations with UVA/UVB. Motegi et al. ${ }^{43}$ evaluated whether UVA-induced photoaging could be accelerated in fibroblasts with existing mutations within the LMNA gene. They cultured fibroblasts derived from patients with atypical progeroid syndrome (APS) and performed single dose irradiation of $100 \mathrm{~kJ} / \mathrm{m}^{2}$ and $200 \mathrm{~kJ} /$ $\mathrm{m}^{2}$ UVA. It was found that UVA irradiation results in increased production of abnormally shaped, HGPS-like cell nuclei in APS fibroblasts, as well as an elevated apoptotic/necrotic rate of these cells in comparison to normal fibroblasts. ${ }^{43}$ It has also been shown that UVA irradiation induces progerin mRNA expression in normal fibroblasts, however, they did not observe UVA-induced progerin accumulation in APS fibroblasts indicating that apoptosis/necrosis in APS fibroblasts does not depend solely on the accumulation of progerin. ${ }^{43}$ There are several limitations to our study; firstly, we did not evaluate the viability and morphology of irradiated cells nor performed an intervention to modulate the cellular response and secondly, we did not evaluate the enzymatic activity of cathepsin $\mathrm{K}$, thus opening the field for further research and discussion.

\section{Conclusion}

Single high-doses of UVA, UVBwb and UVBnb resulted in the decreased expression of cathepsin $\mathrm{K}$ and progerin protein/mRNA in all subsequent time points. Repeated exposure to low doses of UVA results in a significant increase of progerin mRNA and a significant decrease of progerin protein after 48 hours, but repeated exposure to UVBwb and UVBnb resulted in decreased progerin mRNA and protein expression. Repeated exposure to UVA, UVBwb and UVBnb resulted in decreased cathepsin $\mathrm{K}$ protein and mRNA expression. These results suggest that there could be another progerin/cathepsin $\mathrm{K}$ regulatory pathway, which has not been described yet. Having obtained results that contradict previous research, the influence of UVR on progerin and cathepsin $\mathrm{K}$ needs to be further elucidated.

\section{Acknowledgments}

The study was funded by Medical University of Lodz (project no. 503/5-064-01/503-1) and The National Centre of Science (grant nos. 2017/25/N/NZ5/02064 and 2017/27/B/NZ5/02011).

\section{Disclosure}

The authors report no conflicts of interest in this work.

\section{References}

1. Burke KE. Photoaging: the role of oxidative stress. G Ital Dermatol Venereol. 2010;145(4):445-459.

2. de Gruijl FR. Photocarcinogenesis: UVA vs UVB. Methods Enzymol. 2000;319:359-366.

3. Sklar LR, Almutawa F, Lim HW, Hamzavi I. Effects of ultraviolet radiation, visible light, and infrared radiation on erythema and pigmentation: a review. Photochem Photobiol Sci. 2013;12(1):54-64. doi:10.1039/c2pp25152c

4. Pfeifer GP, You Y-H, Besaratinia A. Mutations induced by ultraviolet light. Mutat Res Mol Mech Mutagen. 2005;571(1-2):19-31. doi:10.1016/j.mrfmmm.2004.06.057

5. Poon F, Kang S, Chien AL. Mechanisms and treatments of photoaging. Photodermatol Photoimmunol Photomed. 2015;31(2):65-74. doi:10.1111/phpp. 12145

6. Pittayapruek P, Meephansan J, Prapapan O, Komine M, Ohtsuki M. Role of matrix metalloproteinases in photoaging and photocarcinogenesis. Int J Mol Sci. 2016;17(6):868. doi:10.3390/ijms17060868

7. Xu Q, Hou W, Zheng Y, et al. Ultraviolet A-induced cathepsin K expression is mediated via MAPK/AP-1 pathway in human dermal fibroblasts. PLoS One. 2014;9(7):e102732. doi:10.1371/journal. pone. 0102732

8. Codriansky KA, Quintanilla-Dieck MJ, Gan S, Keady M, Bhawan J, Rünger TM. Intracellular degradation of elastin by cathepsin $\mathrm{k}$ in skin fibroblasts - A possible role in photoaging. Photochem Photobiol. 2009;85(6):1356-1363. doi:10.1111/j.1751-1097.2009.00592.x

9. Bossard MJ, Tomaszek TA, Thompson SK, et al. Proteolytic activity of human osteoclast cathepsin K: expression, purification, activation, and substrate identification. J Biol Chem. 1996;271(21):1251712524. doi:10.1074/jbc.271.21.12517

10. Golovatch P, Mercer BA, Lematre V, Wallace A, Foronjy RF, D'Armiento J. Role for cathepsin $\mathrm{K}$ in emphysema in smoke-exposed guinea pigs. Exp Lung Res. 2009;35(8):631-645. doi:10.3109/ 01902140902822304

11. Rao Q, Wang Y, Xia QY, et al. Cathepsin K in the immunohistochemical diagnosis of melanocytic lesions. Int J Clin Exp Pathol. 2014;7(3):1132-1139.

12. Ishida M, Kojima F, Okabe H. Cathepsin K expression in basal cell carcinoma. J Eur Acad Dermatol Venereol. 2013;27(1):e128-e130. doi:10.1111/j.1468-3083.2011.04436.x

13. Ciążyńska M, Bednarski IA, Wódz K, et al. Impact of ultraviolet radiation on expression of transforming growth factor $\beta, \operatorname{smad} 2$, metalloproteinases- $1,-3,-8,-9$, cathepsin $\mathrm{K}$ and progerin. Photochem Photobiol. 2018;94(2):362-369. doi:10.1111/php.12866

14. Hirai T, Kanda T, Sato K, et al. Cathepsin K is involved in development of psoriasis-like skin lesions through TLR-dependent Th17 activation. J Immunol. 2013;190(9):4805-4811. doi:10.4049/ jimmunol.1200901 
15. Takeuchi H, Rünger TM. Longwave UV light induces the agingassociated progerin. J Invest Dermatol. 2013;133(7):1857-1862. doi:10.1038/jid.2013.71

16. Mcclintock D, Ratner D, Lokuge M, et al. The mutant form of lamin a that causes Hutchinson-Gilford progeria is a biomarker of cellular aging in human skin. PLoS One. 2007;2(12):e1269. doi:10.1371/ journal.pone.0001269

17. De Sandre-giovannoli A, Bernard R, Cau P, et al. Lamin a truncation in Hutchinson-Gilford progeria. Science. 2003;300(5628):2055. doi:10.1126/science. 1084125

18. Cao K, Graziotto JJ, Blair CD, et al. Rapamycin reverses cellular phenotypes and enhances mutant protein clearance in HutchinsonGilford progeria syndrome cells. Sci Transl Med. 2011;3(89):89ra58. doi:10.1126/scitranslmed.3002346

19. Gordon LB, Cao K, Collins FS. Progeria: translational insights from cell biology. $J$ Cell Biol. 2012;199(1):9-13. doi:10.1083/ jcb.201207072

20. Decker ML, Chavez E, Vulto I, Lansdorp PM. Telomere length in Hutchinson-Gilford progeria syndrome. Mech Ageing Dev. 2009;130 (6):377-383. doi:10.1016/j.mad.2009.03.001

21. Musich PR, Zou Y. Genomic instability and DNA damage responses in progeria arising from defective maturation of prelamin A. Aging. 2009;1(1):28-37. doi:10.18632/aging.100012

22. Scaffidi P, Misteli T. Lamin A-Dependent nuclear defects in human aging. Science. 2006;312(5776):1059-1063. doi:10.1126/science.11 27168

23. Burtner CR, Kennedy BK. Progeria syndromes and ageing: what is the connection? Nat Rev Mol Cell Biol. 2010;11(8):567-578. doi:10.1038/nrm2944

24. Skoczyńska A, Budzisz E, Dana A, Rotsztejn H. New look at the role of progerin in skin aging. Prz Menopauzalny. 2015;14(1):53-58. doi:10.5114/pm.2015.49532

25. Fisher GJ, Kang S, Varani J, et al. Mechanisms of photoaging and chronological skin aging. Arch Dermatol. 2002;138(11):1462-1470. doi:10.1001/archderm.138.11.1462

26. D'Orazio J, Jarrett S, Amaro-Ortiz A, Scott T. UV radiation and the skin. Int $J$ Mol Sci. 2013;14(6):12222-12248. doi:10.3390/ ijms140612222

27. Newton VL, McConnell JC, Hibbert SA, Graham HK, Watson REB. Skin aging: molecular pathology, dermal remodelling and the imaging revolution. G Ital Dermatol Venereol. 2015;150(6):665-674.

28. Dong KK, Damaghi N, Picart SD, et al. UV-induced DNA damage initiates release of MMP-1 in human skin. Exp Dermatol. 2008;17 (12):1037-1044. doi:10.1111/j.1600-0625.2008.00747.x

29. Quintanilla-Dieck MJ, Codriansky K, Keady M, Bhawan J, Rünger TM. Expression and regulation of cathepsin K in skin fibroblasts. Exp Dermatol. 2009;18(7):596-602. doi:10.1111/j.1600-0625.2009.0 0855.x

30. Rünger TM, Quintanilla-Dieck MJ, Bhawan J. Role of cathepsin K in the turnover of the dermal extracellular matrix during scar formation. J Invest Dermatol. 2007;127(2):293-297. doi:10.1038/sj.jid.5700535
31. Petricevic SJ, Pavlovic A, Capkun V, Becic K, Durdov MG. Cathepsin $\mathrm{K}$ expression in melanoma is associated with metastases. Histol Histopathol. 2017;32(7):711-716. doi:10.14670/HH-11-833

32. Ciążyńska M, Bednarski IA, Wódz K, et al. Proteins involved in cutaneous basal cell carcinoma development. Oncol Lett. 2018;16(3). doi:10.3892/ol.2018.9126

33. Zheng Y, Lai W, Wan M, Maibach HI. Expression of Cathepsins in human skin photoaging. Skin Pharmacol Physiol. 2010;24(1):10-21. doi:10.1159/000314725

34. Bidault G, Garcia M, Capeau J, Morichon R, Vigouroux C, Béréziat V. Progerin expression induces inflammation, oxidative stress and senescence in human coronary endothelial cells. Cells. 2020;9 (5):1201. doi:10.3390/cells9051201

35. Cohen-Carmon D, Sorek M, Lerner V, et al. Progerin-induced transcriptional changes in huntington's disease human pluripotent stem cell-derived neurons. Mol Neurobiol. 2020;57(3):1768-1777. doi:10.1007/s12035-019-01839-8

36. Tang Y, Chen Y, Jiang H, Nie D. Promotion of tumor development in prostate cancer by progerin. Cancer Cell Int. 2010;10:1. doi:10.1186/ 1475-2867-10-47

37. Dreesen O. Towards delineating the chain of events that cause premature senescence in the accelerated aging syndrome HutchinsonGilford progeria (HGPS). Biochem Society Trans. 2020:48(3):98991. doi:10.1042/BST20190882

38. Lechler T, Fuchs E. Asymmetric cell divisions promote stratification and differentiation of mammalian skin. Nature. 2005;437(7056):275280. doi:10.1038/nature03922

39. Halaschek-Wiener J, Brooks-Wilson A. Progeria of stem cells: stem cell exhaustion in Hutchinson-Gilford progeria syndrome. J Gerontol a Biol Sci Med Sci. 2007;62(1):3-8. doi:10.1093/gerona/62.1.3

40. Rosengardten Y, McKenna T, Grochová D, Eriksson M. Stem cell depletion in Hutchinson-Gilford progeria syndrome. Aging Cell. 2011;10(6):1011-1020. doi:10.1111/j.1474-9726.2011.00743.x

41. Sola-Carvajal A, Revêchon G, Helgadottir HT, et al. Accumulation of progerin affects the symmetry of cell division and is associated with impaired Wnt signaling and the mislocalization of nuclear envelope proteins. $J$ Invest Dermatol. 2019;139(11):2272-2280.e12. doi:10.1016/j.jid.2019.05.005

42. Lesiak A, Bednarski I, Rogowski-Tylman M, et al. One week of exposure to sunlight induces progerin expression in human skin. Postepy Dermatol Alergol. 2017;34(6):629. doi:10.5114/ pdia.2016.62416

43. Motegi SI, Uchiyama A, Yamada K, et al. Increased susceptibility to oxidative stress- and ultraviolet A-induced apoptosis in fibroblasts in atypical progeroid syndrome/atypical Werner syndrome with LMNA mutation. Exp Dermatol. 2016;25(5):20-27. doi:10.1111/exd.13086
Clinical, Cosmetic and Investigational Dermatology is an international, peer-reviewed, open access, online journal that focuses on the latest clinical and experimental research in all aspects of skin disease and cosmetic interventions. This journal is indexed on CAS.
The manuscript management system is completely online and includes a very quick and fair peer-review system, which is all easy to use. Visit http://www.dovepress.com/testimonials.php to read real quotes from published authors. 